\title{
Green Marketing and Green Brand Image on Users-Attitudes of The Body Shop Indonesia
}

\author{
Ida Lestari ${ }^{1 *}$, Dinda Rakhma Fitriani ${ }^{2}$ \\ 1,2 Gunadarma University,Margonda Raya, Depok \\ ${ }^{*}$ Corresponding Author: \\ Email: idalstr130@gmail.com
}

\begin{abstract}
.
This study aims to determine the effect of Green Marketing and Green Brand Image on users attitudes of The Body Shop Indonesia products empirically, either partially or simultaneously. The population in this study are followers of the Instagram account@thebodyshopindo who have purchased The Body Shop products and used them. This study used a sample of 100 respondents where the questionnaire was distributed using google form through social media Instagram. Sampling using purposive sampling method. The data analysis method used multiple linear regression, with partial and simultaneous hypothesis testing and processed using SPSS version 25 for Windows.The results showed that the two independent variables, namely Green Marketing and Green Brand Image, had a positive and significant effect either partially or simultaneously on the dependent variable of user attitudes. In addition, this study explains that user attitudes are influenced by $68.5 \%$ by Green Marketing and Green Brand Image, the remaining 31.5\% is influenced by other factors.
\end{abstract}

Keywords: Green Marketing; Green Brand Image; Instagram; Users Attitudes; The Body Shop

\section{INTRODUCTION}

Currently, the earth is experiencing serious problems, namely environmental damage and global warming caused by the regular use of products containing hazardous chemicals. Based on the calculation of particulate concentration (PM2.5), air quality in Indonesia in 2020 will be 40.7 micrograms per cubic meter ( $\mu \mathrm{gram} / \mathrm{m} 3$ ). With this value, Indonesia was ranked ninth in the list of countries with the worst air quality last year.Gradually the perspective and lifestyle of individuals to business actors have changed to become more concerned with the environment. Awareness makes people as consumers more sensitive and sensitive about the use of the products they will buy. People tend to look for and buy environmentally friendly products. This condition is exploited by business actors by marketing more environmentally friendly products made from natural ingredients (back to nature). Companies try to label their products with environmentally friendly labels or eco-labels and create advertisements that connect these products with environmental protection efforts.Business actors can follow market developments by utilizing the current type of marketing or marketing, one of which is Green Marketing.

Green Marketing or green marketing is a type of marketing that concerns the preservation of the environment and nature as a form of awareness about http://ijstm.inarah.co.id 
environmental damage. According to Heizer and Render, the main purpose of this type of marketing is to develop safe and environmentally friendly products and minimize raw material waste to increase cost-effectiveness (Redaksi, 2020) [13]. Not all companies that produce goods apply Green Marketing. This type of marketing is usually carried out by companies that want to support the sustainable development process to fulfill Corporate Social Responsibility (CSR).The use of Green Marketing by business actors can improve a much better brand image by utilizing environmentally friendly marketing. A Green Brand Image is a perception of a brand that exists in the minds of users that relates the commitment and concern of products or services to the environment (Astini, 2017) [4]. Green Brand Image can increase if the company is active in spreading a zero-waste lifestyle which is defined as a lifestyle with or without the use of plastic waste, where this program encourages lifestyle changes to use reusable resources.One of the companies that pioneered Green Marketing to promote zero waste is The Body Shop Indonesia which has been campaigning Against Animal Testing since 1989.

The Body Shop uses natural ingredients and is free from chemicals and The Body Shop product packaging is also certified by the Forest Steward Council (FSC), namely, the packaging of the products used are from forests that are managed responsibly and provide environmental, social, and economic benefits. In campaigning for the zero waste program, The Body Shop campaigns for Bring Back Our Bottles (BBOB). This campaign has been started by The Body Shop in 2008 until now, this program invites The Body Shop users to return the used packaging bottles to the store in return for being rewarded in the form of points for those who have The Body Shop membership (Marketeers, 2019) [9].The Green Marketing and Green Brand Image approaches used by The Body Shop are carried out to achieve the desires, needs, and intentions of users to contribute to the preservation of the environment and nature. Green Marketing conducted by The Body Shop includes four components of the marketing mix, namely product, price, place and promotion. The consistency of The Body Shop Indonesia received many appreciations such as getting two award categories from PT. Indonesian Natural Wasteforchange (Waste4Change) in the context of Appreciation Day 2020 which was held on December 17, 2020.

The two categories are Zero Waste to Landfill for efforts to reduce waste that ends up in the Final Waste Processing Site (TPA) and Extended Producer Responsibility for efforts to take responsibility for waste from users. The loyalty of The Body Shop products can be seen by following the Instagram account @ thebodyshopindo. This is not only to facilitate user interaction, but also to obtain information about products in all areas. The convenience of the media for users is very effective in finding information to satisfy their need for information that will affect the attitudes of users of The Body Shop Indonesia products. To find out the effect of Green Marketing and Green Brand Image of The Body Shop on the attitudes of its users, the researcher conducted a study entitled The Effect of Green Marketing and Green Brand 
Image on the Attitudes of Users of The Body Shop Indonesia's Products. The formulation of the research problem is "Is there any influence of Green Marketing and Green Brand Image on the attitudes of users of The Body Shop Indonesia products?". This research hypothesizes that there is an influence of Green Marketing and Green Brand Image on the attitudes of users of The Body Shop Indonesia products on Instagram followers@ @thebodyshopindo.

\section{Green Marketing}

Green Marketing is one type of marketing strategy that began to emerge from the late 1980s to the early 1990s. According to Coddington in Paath et al. (2020) [11] what is meant by Green Marketing is all marketing activities that are responsible for the environment, namely by minimizing negative impacts on the environment. According to Kotler \& Keller (2012) [8] there are 4 elements of Green Marketing from the conventional marketing mix consisting of green products, green prices, green places, and green promotions. There are three indicators of green promotion, namely:

1. Eco-label

Eco-label is one way that aims to promote products that pay attention to environmental sustainability or do not cause negative impacts on the environment.

2. Eco-brand

Eco-brand is a form of symbol or name or product design that does not harm the environment.

3. Environmental Advertisement

Green advertising or environmental-themed advertising is used to provide information about environmentally friendly products or services to consumers.

\section{Green Brand Image}

According to Chen (2009) [6] Green Brand Image is a perception of a brand that is in the minds and minds of consumers related to responsibility and concern for the environment of a product or service. According to Keller (Adiwidjaja \& Tarigan, 2017) [2] stated that the measurement indicators of Green Brand Image can be done based on aspects of a brand, namely:

1. Strength of Brand Association

Factors that affect the strength of brand associations are marketing communications that are created to foster a brand image in the minds of audiences (personal relevance) and are consistent marketing communications programs over time and over time.

2. Favorability of Brand Association

Favorability of brand association is created by convincing the public that a brand can have relevant benefits and can fulfill their needs and desires to form a positive brand attitude towards them.

3. Uniqeness of Brand Association 
Uniqueness of brand association is the level of brand uniqueness that has competitive and continuous benefits so that it can cause the target audience to be interested in using it.

\section{Attitude}

According to De Fleur (in Cangara, 2008) [5], influence refers to the difference between the thoughts and behavior of the recipient of the message before and after receiving the message. This influence can affect a person's knowledge, attitudes, and behavior. Effendy (2003) [7] explains the classification of effects as follows:

1. Cognitive Effect

This effect is related to thoughts or reasoning that contains one's beliefs about what is true and applies to the object of attitude.

2. Affective Effect

This effect is related to human feelings that arise from reading newspapers or magazines, listening to the radio, watching TV programs, movies, advertisements, and also from social media.

3. Conative Effect

The conative effect is related to the intention, determination, effort, effort that tends to become an activity or action. The conative component in the attitude structure shows how a person's behavior or behavioral tendency is associated with the attitude object he faces.

\section{Theory of Planned Behavior}

The Theory of Planned Behavior developed by Ajzen is a form of refinement of The Theory Of Reasoned Action proposed by Fishbein and Ajzen (Ajzen, 2005) [3]. Ajzen (2005) [3] emphasizes the rationality of human behavior and the belief that the target behavior is under the conscious control of the individual. This theory aims to define human behavior through intentions or interests based on the hypothesis that individuals make logical and reasoned decisions to engage in certain behaviors by evaluating the information available to them. According to Achmat (2011) [1], the Theory of Planned Behavior is based on the assumption that humans are rational and use information that is possible for them systematically.

\section{Elaboration Likelihood Theory}

This theory was first developed by Richard E. Petty and John T. Cacioppo in 1986. The basic assumption of this theory is that people process persuasive messages in different ways. In this situation, people will assess the message deeply, critically, and carefully, but in other situations, someone will receive the message casually without further processing the content of the message they receive. This theory is a persuasion communication theory because this theory predicts when and how individuals will or will not be affected by the messages they receive. This theory also explains that individuals will evaluate the messages they receive critically. How they respond to messages depends on how someone processes the message. 
The application of this theory aims to change a person's behavior through persuasive communication, the impact will be different based on certain persuasion variables during the communication process. Communicants as message recipients are conditioned to have the motivation and ability to process the messages they receive. A person's motivation can be influenced by several variables, such as personal experience or personal problems related to the messages they receive, feeling comfortable about the messages they receive, the need or desire for something, and a sense of responsibility to process these messages (Petty et al. ., 2012) [12].

\section{METHODS}

This study uses a quantitative approach with a survey method conducted by distributing questionnaires to respondents. The paradigm used in this study is the positivism paradigm. This paradigm aims to confirm causal relationships that can be used to predict general patterns of social phenomena or human activities (Neuman W. L., 2013) [10]. Researchers collected data by conducting observations, literature studies, documentation, online searches, and distributing questionnaires. The population in this study were all followers of the Instagram account @ thebodyshopindo. The research sample was conducted using a purposive sampling technique with the following characteristics:

1. Instagram social media users

2. Follow the @thebodyshopindo account

3. Have you ever bought The Body Shop products?

4. Have you ever used The Body Shop products?

The sample value obtained using the Slovin formula yields a value of 100. The research variables consist of Green Marketing (X1), Green Brand Image (X2), and Attitude (Y). The measurement of the data was carried out using a Likert scale with a value of $1-4$. The data was then processed and analyzed using several statistical tests starting with validity testing, reliability testing, classical assumption testing, and hypothesis testing. Classical assumption test is done by normality test, multicollinearity test, heteroscedasticity test, and multiple linear tests, while hypothesis testing is done by T-test and F test. In this study, researchers used SPSS version 25 for Windows as a data processing tool and also to perform testing. data analysis.

\section{RESULT AND DISCUSSION}

This research was conducted by first conducting a pre-test to ensure that the measuring instrument or instrument was tested for validity and reliability. Then, after that, the researchers conducted real research by distributing questionnaires to respondents who were followers of the @ thebodyshopindo Instagram account. After the questionnaire was completed, the researcher began to analyze the correlation coefficient on the data obtained regarding the variables of Green Marketing, Green 
Brand Image, and attitudes of users of The Body Shop Indonesia.A pre-test on 40 respondents was conducted to test the validity and reliability of the questionnaire. The results of the validity test show that all statement items are valid because they have a value of $r_{\text {count }}>r_{\text {table. }}$. Furthermore, after conducting the pre-test, it was finally found that the instrument had a higher level of reliability for each variable, where the Cronbach Alpha value of each variable was $>0.6$, then the measuring instrument used was reliable.

Table 1. Reliability Test Results

\begin{tabular}{ccc}
\hline Variabel & Cronbach Alpha & Keterangan \\
\hline Green Marketing $\left(\mathrm{X}_{1}\right)$ & 0.764 & Reliabel \\
\hline Green Brand Image $\left(\mathrm{X}_{2}\right)$ & 0.770 & Reliabel \\
\hline Users-Attitude $(\mathrm{Y})$ & 0.755 & Reliabel \\
\hline
\end{tabular}

Table 1. shows that all research instruments, namely Green Marketing, Green Brand Image, and user attitudes have a Cronbach Alpha greater than 0.60 which indicates that the statement on the questionnaire is reliable so that it can be used to conduct research. Furthermore, the results of the analysis show the KolmogorovSmirnov $Z$ value of 1,072 with the Asymp Sig value. (2-tailed) of 0.201 is greater than the alpha value of 0.05 .This analysis is used to find the regression coefficient that will determine whether the hypothesis made will be accepted or rejected. A multiple linear regression model is used to explain the effect of independent variables on the dependent variable. The purpose of this study was to determine the effect of Green Marketing and Green Brand Image on the attitudes of users (Y) of The Body Shop Indonesia. The results of multiple linear regression analysis can be seen in detail as follows:

$$
\begin{array}{lll}
\mathrm{Y}^{\prime} & =0.589\left(\mathrm{X}_{1}\right)+2.016\left(\mathrm{X}_{2}\right) \\
\mathrm{SE} & =0.214\left(\mathrm{X}_{1}\right) & 0.274\left(\mathrm{X}_{2}\right) \\
\mathrm{t} & =2.754\left(\mathrm{X}_{1}\right) & 7.354\left(\mathrm{X}_{2}\right) \\
\text { Sig. } & =0.007\left(\mathrm{X}_{1}\right) & 0.000\left(\mathrm{X}_{2}\right) \\
\mathrm{R}^{2} & =0.685 \mathrm{~F}=105.672 \quad \text { Sig. }=0.000
\end{array}
$$

The results of the F-test calculation show a number of 105,672, with a significance of 0.000 . The figure shows that $\mathrm{H}_{0}$ is rejected and $\mathrm{H}_{1}$ is accepted. So, it can be concluded that simultaneously or jointly the Green Marketing (X1) and Green Brand Image (X2) variables have an effect on the attitudes of The Body Shop Indonesia users. The coefficient of determination or adjusted R2 $=0.685$ means that $68.5 \%$ of variations in user attitudes can be influenced by Green Marketing and Green Brand Image, while the remaining $31.5 \%$ is influenced by other factors not discussed in this study.From these figures, it can be explained that the Green Marketing and Green Brand Image variables have a significant effect on user attitudes. If the utilization of the two marketing strategies increases, the better, it will have a positive effect on the attitudes of users of The Body Shop Indonesia. 
Based on the results of statistical analysis, there is an influence between Green Marketing and the Green Brand Image of the implementation of the Zero Waste program on the attitudes of users of The Body Shop Indonesia products. The use of marketing strategies, namely Green Marketing according to Kotler and Keller (2012:15) through Green Promotion with measuring instrument indicators, namely (1) Eco-Label, (2) Eco-Brand, and (3) Environmental Advertisement. As for the Green Brand Image measurement indicators can be done based on aspects of a brand, namely (1) Strength of brand association, (2) Favorability of brand association, and (3) Uniqueness of brand association.

When they see Green Marketing through Green Promotion conducted by The Body Shop Indonesia, users also dare to pay more and are loyal to products and brands that use Green Marketing, so that the Green Brand Image of The Body Shop will also increase. Draft Green Marketing in Indonesia is a form of shifting community values that are starting to be widely discussed. Seeing Green Marketing will affect the user's attitude towards The Body Shop and its products.Green Marketing The Body Shop can provide understanding, awareness, and create a sense to take an action to users. Thus the understanding, awareness, and consumer actions towards Green Marketing will be higher and can form attitudes based on cognitive, affective, and conative aspects to improve the Green Brand Image.In this way, The Body Shop's brand image will increase in line with The Body Shop's desire to become an environmentally friendly company, because The Body Shop's developing brand image is influenced by user attitudes through Green Marketing.

Researchers used two theories in analyzing quantitative data in this study. The theory used is Theory of Planned Behavior and Theory of Elaboration Likelihood. The Theory of Planned Behavior was first developed by Ajzen. Where this theory studies a person's behavior in decision making. This theory aims to define human behavior through intentions or interests. In The Theory Of Planned Behavior, Ajzen emphasizes the rationality of human behavior and the belief that target behavior is under the control of individual consciousness. Consists of three factors such as the formation of individual attitudes towards behavior perceived behavioral control and subjective norms.It is postulated that a person's intention to perform a certain behavior is influenced by attitude, i.e. someone who believes that the behavior can produce positive results, then the individual has a positive attitude and vice versa, then perceived behavioral control, namely the extent to which consumers feel they can control their behavior. them towards certain actions, and subjective norms, namely the interests of other people's opinions.

Judging from the research results obtained by Green Marketing from The Body Shop Indonesia, it will form a response to the product and the company and can influence intentions, interests, individual awareness, motivation, and ability to process messages. This marketing strategy is used by The Body Shop in the midst of 
environmental issues that are increasingly being heard in the community. Being one of the pioneers of Green Marketing activists, The Body Shop is also intensively campaigning on the environment by producing products made from natural, environmentally friendly, and against animal testing to preserve the environment and nature.The public's intention arises because The Body Shop is able to attract the attention of consumers with the values adopted by this company. In addition to the fact that The Body Shop uses natural ingredients and is free from chemicals, The Body Shop's packaging is also certified by the Forest Steward Council (FSC), namely, the packaging of the products used come from forests that are managed responsibly and provide environmental, social, and environmental benefits. and economy.

Public awareness of the current environmental and natural conditions has changed the perspective and lifestyle of individuals to business actors. People are aware that the use of products made from natural and environmentally friendly can preserve the environment. With this change, there will be a public interest in buying the product and can feel the benefits arising from the use and purchase of the product. The Body Shop promotes its products through environmental campaigns, posters, leaflets, and others as products that use $100 \%$ natural and environmentally friendly ingredients. This further shows that The Body Shop as one of the most influential companies in the world can demonstrate the quality of its products and fight for its mission for social progress. The public also hopes that The Body Shop needs to obtain an ISO 14000 certificate in order to convince the public that The Body Shop is an environmentally friendly product. With The Body Shop being able to convince the public with the quality of its products, they will be more motivated to use The Body Shop products and buy them because they believe that these products are better than other products. So that every product produced can provide assurance to consumers who use and buy that the product does not have a negative impact on the environment.

In promoting its products, The Body Shop utilizes advertisements and campaigns that carry environmental themes to attract the attention of product users. The forms of advertising and campaigns used by The Body Shop are able to make users understand the message that The Body Shop wants and make them look for more information about The Body Shop products. The more users trust The Body Shop products, the they will also be willing to promote these products to others and be loyal to use and buy The Body Shop products.Based on the results of hypothesis testing, it shows that Green Marketing (X1) and Green Brand Image (X2) variables simultaneously affect attitudes (Y), then $\mathrm{H} 0$ is rejected and $\mathrm{H} 3$ is accepted. This is in line with previous research by I Gusti Agung Nanda Dwipamurti, M. Kholid Mawardi, and Inggang Perwangsa Nurahan in 2018 which discussed The Effects Of Green Marketing On Brand Image And Purchase Decision (Study On Consumer Of Starbucks Café Ubud, Gianyar Bali ) which results that Green Marketing, Brand Image, and Purchase Decision have a significant influence on each other. 
A purchase decision is a selection process that results in a decision to buy or not to buy a product, goods, or service. In the process, the individual must go through the combination of knowledge, feelings to become a consideration that can take what action will be taken. This decision is made by users or potential users to decide what brand or product to buy. They will choose based on how they perceive the product and brand of the item and the situation that is not expected to occur. So it can be concluded that user attitudes affect user decisions and loyalty to the products and brands of goods they will buy through the knowledge process in processing information from existing messages, feelings, motivations, intentions, to the awareness that they have to be considered for their actions.

\section{CONCLUSION}

It was found that the simultaneous positive and significant influence of Green Marketing and Green Brand Image on the attitudes of users of The Body Shop Indonesia products on Instagram followers @ thebodyshopindo. Based on the results of the coefficient of determination, the R Square value was $68.5 \%$. This means that the percentage contribution of the Green Marketing (X1) and Green Brand Image (X2) variables is $68.5 \%$, while the remaining $31.5 \%$ is influenced by other factors not discussed in this study.The Body Shop Indonesia needs to maintain and improve the implementation of Green Marketing and Green Brand Image strategies to win the competition and build trust for users so that they don't doubt the quality of The Body Shop and become 'Top of Mind' in society. The increasing public awareness of environmental and natural preservation can be utilized by The Body Shop to use this strategy in expanding its market share.

One way is to be more active in delivering environmental-based campaigns so that consumers and users know the advantages of The Body Shop and help the government increase public awareness of the environment and social issues.For future research in primary data collection, it can also be done by conducting field observations, direct interviews with respondents so that the results of the analysis obtained are comprehensive. Further researchers can also increase variables such as Green Trust, Green Brand Positioning, Green Quality, Green Customer Loyalty, and others that can be added in further research to add a wider perspective and form The Body Shop in determining marketing strategies that are appropriate. good. Further researchers can also conduct studies on other brands in order to obtain varied results. In addition, further researchers can increase the number of samples so that the scope is wider.

\section{ACKNOWLEDGMENTS}

The researcher would like to thank Dr. Dinda Rakhma Fitriani who is willing to guide the end of this research, to all respondents who are willing to take the time and 
to all parties involved either directly or indirectly in the process of collecting and processing data.

\section{REFERENCES}

[1] Achmat, Z. (2011). Theory Of Planned Behavior, Masihkah Relevan?Universitas Muhammadiyah

Malang.

https://scholar.google.com/citations?view_op=view_citation\&hl=en\&user=28cPDPwAA AAJ\&citation for_view=28cPDPwAAAAJ:u5HHmVD_uO8C

[2] Adiwidjaja, Adrian Jnio., \& Tarigan, Zeplin Jiwa Husada. (2017). Pengaruh Brand Image dan Brand Trust Terhadap Keputusan Pembelian Sepatu Converse. Agora, Jurnal Mahasiswa Manajemen Bisnis 2017(5)

[3] Ajzen, I. (2005). Attitudes, personality, and behavior. McGraw Hill.

[4] Astini, R. (2017). Implikasi Green Brand Image, Green Satisfaction Dan Green Trust Terhadap Loyalitas Pelanggan (Studi Kasus Pada Konsumen AMDK Galon Merk AQUA di Wilayah Serpong Utara). Jurnal Manajemen, 20(1). https://doi.org/https://doi.org/10.24912/jm.v20i1.63

[5] Cangara, H. (2008). Pengantar Ilmu Komunikasi. Rajawali Pers.

[6] Chen, Y.-S. (2009). The Drivers of Green Brand Equity: Green Brand Image, Green Satisfaction, and Green Trust. Journal of Business Ethics, 93(2), 307-319.

[7] Effendy, O. U. (2003). Dinamika Komunikasi. Remaja Rosdakarya.

[8] Kotler, Philip., \& Keller, Kevin Lane. (2012). Marketing Management. $14^{\text {th }}$ Prentice Hall, New Jersey

[9] Marketeers. (2019). The Body Shop: Sustainability and Zero Waste is a New Marketing Approach.

Www.Marketeers.Com. https://www.marketeers.com/the-body-shop-sustainability-andzero-waste-is-a-new-marketing-approach/

[10] Neuman W. L. (2013). Metodologi Penelitian Sosial: Pendekatan Kualitatif dan Kuantitatif. Indeks.

[11] Paath, D. E., Tampi. J. R. E., \& Mukuan. D. D. S. (2020). Green Marketing terhadap Keputusan Pembelian pada Starbucks Manado Town Square. Productivity, 1 (3), 274278

[12] Petty, R. E., Cacioppo, J. T., \& Schumann, D. (2012). Central and peripheral routes to advertising effectiveness: The moderatig role of involvement. Journal of Consumer Research, 10, 135-146.

[13] Redaksi. (2020). Strategi Green Marketing The Body Shop Indonesia: Sukses atau Gagal? Marketing.Co.Id. https://marketing.co.id/strategi-green-marketing-the-bodyshop-indonesia-sukses-atau-gagal/ 